\title{
FURTHER STUDIES ON CHEMICAL CONTROL OF ARGENTINE STEM WEEVIL IN NORTHERN NORTH ISLAND PASTURES
}

\author{
R.A. PRESTIDGE, D. BADAN, S. VAN DER ZIJPP and D.R. \\ LAUREN
}

Ruakura Soil and Plant Research Station, MAF, Private Bag, Hamilton

\section{SUMMARY}

A single summer treatment, a dual summer treatment with applications 3 weeks apart, and treatments applied every 10-14 days from spring, of oxamyl $(0.48 \mathrm{~kg}$ ai/ha) gave $67 \%, 78 \%$ and $90 \%$ control respectively of Argentine stem weevil (Listronotus bonariensis) larvae. This increased Manawa ryegrass (Lolium $x$ hybridum) production relative to untreated by 3.5, 4.3 and 4.8 times respectively, from January to April 1984. Spring and early summer applications of terbufos and PP 993 granules gave $18-30 \%$ control of stem weevil larvae and failed to significantly increase January to April ryegrass production. A dual midsummer application of PP 993 gave $85 \%$ control of stem weevil but did not significantly increase ryegrass production from January to April.

\section{INTRODUCTION}

There is little information on chemical control of stem weevil in pastures. Research into chemical field control of stem weevil has concentrated primarily on ryegrass seed crops and maize. In young pastures of perennial ryegrass/white clover, dry matter production losses of up to $20 \%$ annually have been recorded (Kain et al 1977; Prestidge unpubl. data). Tiller and herbage production losses are considerably greater in endophyte-free ryegrasses such as Italian, hybrid and tetraploid varieties than in endophyte-infected ryegrasses (e.g. Prestidge et al 1982; Barker et al 1984). Although endophyte-infected ryegrass is the most practical control for stem weevil in pastures, insecticidal controls are still necessary in special purpose endophyte-free pastures.

Prestidge et al (1983) reported that insecticides need to be applied only against the second generation of stem weevil in northern North Island pastures in order to prevent major pasture loss. They found that two applications of oxamyl $(0.48 \mathrm{~kg}$ ai $/ \mathrm{ha}) 3$ weeks apart in mid-summer gave as good stem weevil control as regular 10-14 day applications from early spring to late summer. One summer application gave good initial control of adults and larvae but adults rapidly recolonised and subsequent larval development caused considerable tiller damage and ryegrass production losses. This paper reports on further evaluation of these treatments and a comparison with two surface-broadcast granular insecticides for control of stem weevil in North Island pasture.

\section{METHODS}

The trial area was drilled with 'Grasslands Manawa' ryegrass at $25 \mathrm{~kg} / \mathrm{ha}$ in autumn 1983 into a pasture previously treated with glyphosate (Roundup) at Rukuhia on a Horotiu sandy loam soil. During establishment, the area was lightly grazed with sheep. Picloram +2,4-D (Tordon $50 \mathrm{D}, 0.05+0.2 \mathrm{~kg}$ ai $/ \mathrm{ha}$ ) was applied to the area in early spring to control weeds and clovers.

Plot size was $10 \times 10 \mathrm{~m}$ with four replicates of each treatment in a randomised block design. The insecticides used and rates of application are given in Table 1 . Chemicals were applied either by hand shaker or by precision "Mystifier" knapsack sprayer in 250 litres/ha.

Proc. 37th N.Z. Weed and Pest Control Conf. 
Argentine stem weevil eggs were monitored in control areas at regular intervals to determine the appropriate time to apply insecticide. Eggs were counted from 200 randomly collected ryegrass tillers from each untreated plot. Oxamyl insecticide treatments were applied about a fortnight after the egg numbers reached their peak (Table 1). PP 993 was applied prior to and during peak oviposition as earlier work had suggested an ovaricidal effect. Terbufos was applied in spring on advice from the parent company field representative.

Treatment effects were assessed on 10.2.84 and 24.2.84. Eggs were removed from 200 randomly collected ryegrass tillers from each plot and the larvae were heat extracted from these tillers by the method of Goldson (1978). The number of ryegrass tillers killed by stem weevil was assessed by taking ten $5 \mathrm{~cm}$ diam. soil cores/plot and counting the number of live and killed tillers. All samples were taken at least $2 \mathrm{~m}$ from the plot borders to minimise edge effects.

Pasture production was estimated every 3-4 weeks using rotary lawn mowers (2 swaths/plot) and the area was grazed with sheep immediately following each cut. The percentage of ryegrass present was estimated at every second production cut by herbage dissection.

Results were analysed by analysis of variance as $\log (n+1)($ Table 1$)$. Least significant ratios $(5 \%)$ are given in Table 1 and treatments are significantly different from each other if the ratio of the larger to the smaller value exceeds the LSR.

\section{RESULTS AND DISCUSSION}

The egg numbers used to determine treatment times showed a small peak in early October and a larger peak in mid-January which is typical of northern North Island pastures (Barker and Pottinger 1982; Prestidge et al 1983). Oxamyl treatments were applied about a fortnight after each peak but concentrated on the pasture-damaging second generation of stem weevil.

Oxamyl at 10-14 day intervals and the dual summer oxamyl treatment gave similar control of stem weevil larvae (Table 1), and one summer treatment of oxamyl gave much better control, than in the previous year's trial (Prestidge et al 1983). The only granular insecticide treatment to significantly reduce stem weevil larval populations compared to untreated was the later application of PP 993.

TABLE 1: Control of Argentine stem weevil larvae. Regular 10-14 day treatments commenced on 14.10.83. Products used were Vydate 24 NAC (oxamyl), PP 993 IG, and Counter 20G (terbufos).

\begin{tabular}{|c|c|c|c|c|}
\hline $\begin{array}{l}\text { Treatment } \\
\text { number }\end{array}$ & Chemcial & $\begin{array}{l}\text { Rate of application } \\
\mathrm{kg} \mathrm{ai} / \mathrm{ha}\end{array}$ & $\begin{array}{c}\text { Date of } \\
\text { application }\end{array}$ & $\begin{array}{c}\% \text { of } \\
\text { untreated } \\
\text { population }\end{array}$ \\
\hline 1 & oxamyl & 0.48 & 10-14 day intervals & 10 \\
\hline 2 & oxamyl & 0.48 & 20 Jan 84 & 33 \\
\hline 3 & oxamyl & 0.48 & 20 Jan 84,10 Feb 84 & 22 \\
\hline 4 & PP 993 & 0.10 & $9 \operatorname{Dec} 83,9$ Jan 84 & 83 \\
\hline 5 & PP 993 & 0.10 & 9 Jan 84,1 Feb 84 & 15 \\
\hline 6 & terbufos & 1.00 & 6 Oct 83 & 70 \\
\hline 7 & terbufos & 1.50 & 6 Oct 83 & 82 \\
\hline 8 & $\begin{array}{l}\text { LSR } 5 \% \\
\text { Untreated } \\
\text { tillers) }\end{array}$ & (larvae/200 & & $\begin{array}{l}2.67 \\
9.5\end{array}$ \\
\hline
\end{tabular}




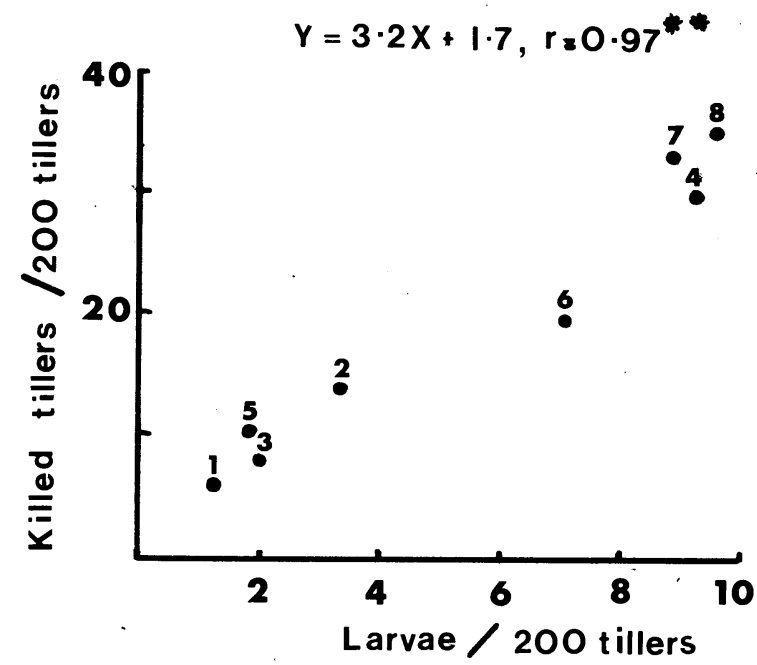

Fig 1: The relationship between stem weevil larval populatons and tiller damage. Numbers correspond to treatments in Table 1.

There was a signficant linear relationship between the number of ryegrass tillers killed by stem weevil and the number of larvae per tiller (Fig 1). There was also a significant negative relationship between the number of tillers killed by stem weevil and ryegrass production from January to April $(\mathrm{Y}=-26 \mathrm{X}+1441, \mathrm{r}=-0.72, \mathrm{P}<0.05)$.

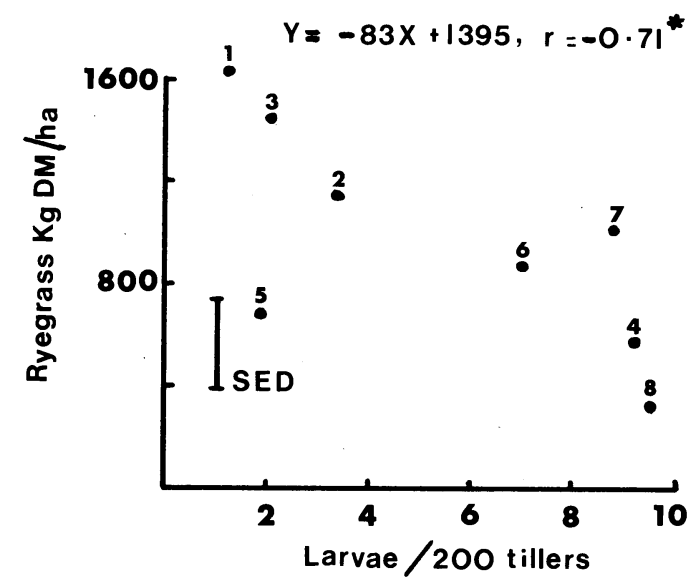

Fig 2: The relationship between stem weevil larval populations and ryegrass production from Jan-April 1984. Numbers correspond to treatments in Table 1.

Ryegrass production from January to April was negatively correlated with the number of stem weevil larvae per tiller (Fig 2). In contrast, there was a poor correlation between ryegrass production from October 1983 to January 1984, before significant stem weevil damage occurred, and the number of larvae per tiller $(r=0.26, P>0.10)$. These results suggest that the effects of the chemical treatments on ryegrass production over the main 
period of stem weevil attack, January to April, were directly attributable to their effects on stem weevil larval populations. Ryegrass production over this period was significantly increased compared to untreated by all oxamyl treatments (Fig 2). Oxamyl 10-14 day applications and the dual summer oxamyl treatment further increased ryegrass production relative to the granular insecticide treatments. The pasture response to the January/February treatment of PP 993 (Fig 2) was lower than expected in view of the effects of this treatment on larval numbers (Table 1) and tiller damage (Fig 1).

While the January to April pasture responses to these insecticides appear to be accounted for by their effects on stem weevil populations, both terbufos treatments (unlike other treatments) gave significant $(P<0.05)$ increases in ryegrass production compared to untreated over the October 1983-January 1984 period, before stem weevil damage occurred. This may have reflected an initial effect of terbufos on other pests following application in October, although soldier fly (Inopus rubriceps), grass grub (Costelytra zealandica) and black beetle (Heteronychus arator) were only present in low numbers on the trial site and plant pathogenic nematodes do not appear to be significant pests in this area (Yeates et al 1983). Similar pasture responses unrelated to stem weevil control have been observed with omethoate (Folimat $58 \mathrm{EC}$ ) applied at 0.50 $\mathrm{kg}$ ai/ha at 10-14 day intervals from early spring to late summer (Prestidge unpublished information). Some systemic insecticides may have a direct positive effect on pasture growth that is unrelated to pest control (Yeates et al 1983).

This trial has confirmed the effectiveness of two applications of foliar sprays of oxamyl for controlling Argentine stem weevil in northern North Island pastures. The first spray should be applied approximately 2 weeks after peak egg laying in January, with 2-3 weeks between applications. A single summer application of oxamyl, dual summer applications of PP 993 granules and possibly summer applications of terbufos granules require futher evaluation. Less expensive insecticides are available (eg Pottinger et al 1984) but their usefulness in pastures has yet to be assessed.

\section{ACKNOWLEDGEMENTS}

Ms B. Dow for biometrical analysis and Rod East for assistance in rewriting the manuscript.

\section{REFERENCES}

Barker, G.M. and Pottinger, R.P., 1982. Preliminary studies on the population' biology of Listronotus bonariensis (Kuschel) (Curculionidae). Proc. 3rd Australasian Conf. Grassland Invert. Ecol.: 95-100.

Barker, G.M., Pottinger, R.P. and Addison, P.J., 1984. Effects of Argentine stem weevil on productivity of grasses in the Waikato. N.Z. J. Ag. Res. 27: In press.

Goldson, S.L., 1978. A simple technique for extracting Argentine stem weevil from ryegrass tillers. N.Z. Ent. 6: 437.

Kain, W.M., Ritchie, I.M., Crouchley, C.G., Smith, R.G. and Atkinson, D.S., 1977. Effects of stem weevil on grazed swards of perennial ryegrasses in Wairarapa and Manawatu. Proc. 30th N.Z. Weed and Pest Control Conf.: 192-197.

Pottinger, R.P., Barker, G.M., Wrenn, N.R. Addison, P.J. and McGhie, R.A., 1984. Insecticidal control of adult Argentine stem weevil: A review and bioassay evaluations. Proc. 37th N.Z. Weed and Pest Control Conf.: (This volume).

Prestidge, R.A., Pottinger, R.P. and Barker, G.M., 1982. An association of Lolium endopyte with ryegrass resistance to Argentine stem weevil. Proc. 35th N.Z. Weed and Pest Control Conf: : 119-122.

Prestidge, R.A., Van der Zijpp, S. and Badan, D., 1983. Chemical control of Argentine stem weevil in North Island pasture. Proc. 36th N.Z. Weed and Pest Control Conf.: 225-228.

Yeates, G.W., Barker, G.M. and Pottinger, R.P. 1983. Effects of oxamyl and carbofuran on nematode populations below 10 grass cultivars. N.Z.J. Exp: Ag. 11: $147-151$. 